behind its continued, separate existence. ${ }^{104}$ Wholly aside from the practical interests of pressure groups, there is persuasive justification for the continued preservation of special minimum wages on Government contracts. A government definitely committed to a general policy of raising wages should require the wages of laborers on its own contracts to reflect the objectives which it seeks to promote. ${ }^{165}$ The prevailing minimum wage is a device peculiarly adapted to the attainment of this end, for it is flexible and yet projects a minimum wage for a given industry which is closely related to actual minimum wage conditions in that particular industry.

The general outline of future wage determinations may be sketched in those which have already been made. Thus far the Public Contracts Division can claim credit for a significant administrative achievement. To a tenuous and unprecedented statutory formula it has given definition, content and a reach of application which on the whole admirably combine the objective of a fair minimum wage with the concrete dictates of wage conditions within the several industries. The process of development has by no means reached its end. Other industries will inevitably raise new problems. But the ruder lines of demarcation have now been drawn, and the problem in the future will be that of fitting within their confines the critical peculiarities of given industries.

\title{
OVER-THE-COUNTER TRADING AND THE MALONEY ACT*
}

I.

From the very beginning of Federal regulation of the distribution and trading of securities it has been recognized that adequate control of the national security exchanges could not alone assure the protection of investors. ${ }^{1}$ To have left the over-the-counter markets out of a regulatory system would in large measure have dissipated the benefits expected to accrue from regulation of organized exchanges. ${ }^{2}$ Congress therefore provided in the Securities Exchange

164. The Walsh-Healey Act was backed strongly from the beginning by the Ameriean Federation of Labor. See SO Cong. Rec. 10003 (1936) (telegram by William Green to the members of the House Judiciary Committee). It has since also been favored by the C.I.O. See N. Y. Times, July 24, 1938, p. 5, col. 4; July 28, 1938, p. 5, col. 6 .

165. See Hearings before Stbcommittee of Honse Committec on Judiciary on H.R. Ir554, 74th Cong., 2d Sess. (1936), 222-223 (statement by the Seeretary of Labor).

*This is the first of two comments on the proposed regulation of oter-the-counter markets. It attempts only to acquaint the reader with the nature and extent of the problem to be solved. A detailed analysis of the mechanies of regulation and the praetices to be controlled will appear in a later issue after more specific steps to malse the Maloney Act operative have been taken by the Commission and the industry.

1. Address of William O. Douglas, before the Bond Club of Hartford, S.E.C. Release (Jan. 7, 1938) 1.

2. Twentieth Century Fund, Stock Market Control (1934) 16. 
Act of 1934 that the Securities and Exchange Commission be granted powers to adopt rules and regulations concerning the over-the-counter markets "necessary or appropriate in the public interest ... . to insure investors protection comparable to that provided by and under authority of this title in the case of national securities exchanges." 3 The generality of this provision was tunavoidable because of Congressional ignorance concerning the precise nature and extent of the problems which were believed inherent in over-the-counter markets. ${ }^{4}$

The Maloney Act ${ }^{5}$ is the result of some four years of research and study by both the Commission and representatives of the over-the-counter industry." Preceded by a number of preliminary amendments to the Securities Exchange Act which have paved the way for its introduction, ${ }^{7}$ the Maloney Act consists of two basic provisions. First, it provides for the creation of voluntary selfregulatory associations of investment bankers, brokers and clealers with powers to adopt rules and regulations and to enforce them with effective economic sanctions. ${ }^{8}$ Secondly, it grants to the Commission certain residuary powers over the entire over-the-counter industry, whether connected with the voluntary associations or not. ${ }^{9}$ This program is based upon cooperative regulation in which the burden will be largely borne by representative organizations of firms and individuals within the industry, with the Government exercising appropriate supervision and supplementary powers of direct regulation. ${ }^{10}$

3. 48 STAT. 895,15 U. S. C. $\$ 780$ (1934).

4. Address of Chester T. Lane, before Investment Bankers' Association of America at San Francisco, California, S.E.C. Release (March 11, 1938) 5.

5. 52 Srat. 1075,15 U.S. C. $\$ \$ 780(\mathrm{c}), 780-3,78 \mathrm{q}(\mathrm{a}), 78 \mathrm{cc}(\mathrm{b}), 78 \mathrm{ft}$ (c) (Supp. 1938). The Maloney Act actually consists of one new section and four amendments to the Securities Exchange Act of 1934. 48 STAт. 881, 15 U. S. C. $\$ \$ 78 a-78 j j$ (1934).

6. See statement of Hon. Francis T. Maloney, Hearings before Committec on Banking and Currency on S.3255, 75th Cong., 3d Sess. (1938) 6.

7. In 1936 the Commission recommended and Congress adopted a new Section 15. In Section 15(a) it provided that no broker or dealer should use the mails or facilities of interstate commerce unless he was registered with the S.E.C. Provision was made in Section 15(b) for registration and the Commission was empowered to deny registration or revoke it for a few rather elementary causes. Section 15 (c) forbade the use of mails and interstate commerce facilities to any who might use them to effect any transactions which under the Commission's rules were defined as manipulative, fratudulent or deceptive. While Section 15(c) applied to all securities transactions, Section 15(a) and (b) specifically exempted brokers and dealers devoting themselves exclusively to the purchase and sale of municipal securities. 49 STAT. 1377 (1936), 15 U. S. C. \$780 (Supp. 1937).

8. Francis A. Bonner, speaking before the annual convention of the Investment Bankers' Association of America said, "We must remember the vital fact that Congress has done perhaps an unprecedented thing in removing restrictions of anti-trust laws from this effort." S.E.C. Release (October 28, 1938) 5. He was referring to Section 1 (i) (1) which provides that the rules of a registered association may require members to deal with non-member brokers and dealers on the same basis as with the public as far as fees, discounts and commissions are concerned.

9. 52 Stat. 1075,15 U. S.C. $\$ 780-3$ (Supp. 1938).

10. Sen. Rep. No. 1455, 75th Cong., 3d Sess. (1938) 4. 
The business included within the scope of the new legislation is a far more important part of our national economy than is generally realized. ${ }^{11}$ The arbitrary statement that under the Securities Exchange Act the over-thecounter markets consist of and include all transactions in securities which do not take place on a national exchange gives but a vague picture of their true character and function. An exchange, in theory, furnishes a public market where buyers and sellers concentrate and where transactions are effected by the meeting of the highest bid and the lowest offer under auction rules. ${ }^{12}$ Contrasted with this, the over-the-counter markets offer no such concentration of traders. Rather they consist of an uncounted number of separate transactions, private bargains where buyer and seller, or their respective agents, deal directly with each other. No publicized record of transactions is kept; no general information as to either volume or price in any given transaction is available. ${ }^{13}$ Each firm participating in over-the-counter trading depends upon independently acquired information as to what other firms in the business are buying or selling, or are likely to buy or sell.14 The whole loose structure is held together by a maze of telephone wires, personal relationships, inter-firm correspondence and a number of private services which enable overthe-counter houses to make their quotations available to one another. ${ }^{15}$ Newspaper quotations of the average bid and asked price of the more frequently traded securities constitute the public's only readily available source of information in regard to over-the-counter prices. ${ }^{10}$

There are certain characteristics inherent in the informal over-the-counter markets which make them the natural media for dealing in certain types of securities. ${ }^{\mathbf{1 7}}$ Of great importance is the fact that the primary operations of the great underwriting houses take place in these unorganized markets. ${ }^{18}$ The absence of publicity as to volume of trading enables these markets success-

11. Twentieth Century Fund, The Security MI.arkets (1935) 269.

12. S.E.C. Report on the Segregation of the Functions of Deales aso Broker (1936) 65.

13. Ibid.

14. Twenteter Century Fund, The Security Mlarkets (1935) 265.

15. Id. at 266 .

16. See Statement of James M. Landis, Hearings before Conmiltec on Banling and Currency on S. 7023 , 74th Cong., 2d Sess. (1936) 12.

17. A dealer in this field has listed the characteristics of a security, any one or more of which make it appropriate for over-the-counter trading, as follows:

1. Lack of speculative interest.

2. Small capitalization.

3. Limited distribution.

4. High price.

5. Desirability for portfolios of insurance companies, investment trusts and other similar institutional investors.

Meyer Willet, Oz'er-the-Counter Possibilities, Wall Strect Journal, December 28, 1931, p. 4 , col. 3 .

18. Hearings before Committec on Banking and Currency on S.3255, 75th Cong., 3d Sess. (1938) 13. 
fully to handle large block buying or selling by institutional investors, whether of unlisted or listed securities, without disrupting prices; a restlt which could not be achieved if transactions of similar size were attempted upon an exchange. ${ }^{19}$ High grade bonds, preferred stocks and guaranteed common stocks with fixed returns, all securities with little speculative appeal, find their medium of trading over-the-counter. ${ }^{20}$ The securities of banks and insurance companies, institutions whose public prestige could not survive the publicity of speculative onslaughts were their issues bought and sold on an exchange, are traded primarily over-the-counter. ${ }^{21}$ Securities of corporations which for one reason or another are not listed on exchanges, whether because of small capitalization, lack of national interest or the unwillingness of the corporation to furnish information necessary for listing, must all go to the unorganized markets. ${ }^{22}$ The obligations of the Federal Government, the states and municipalities are sold almost exclusively over-the-counter. ${ }^{23}$ And in addition to all these, there are the individual transactions which seek the secrecy of the overthe-counter markets to avoid some responsibility of the participants, such as the duty of a director not to deal on an exchange in the securities of his corporation when he has confidential information as to its corporate policy. ${ }^{2.4}$ While it is difficult to estimate the actual money value of securities handled over-the-counter in any given period of time, it may safely be stated that in the number of people engaged, in the volume of business done, and in the number of investors directly affected, the over-the-counter markets substantially exceed their more conspicuous relatives, the securities exchanges.25

Such are the nature and dimensions of that portion of the securities business with which the Maloney Act concerns itself. The Act does not enlarge the

19. Twentieth Century Fund, The Securaty Markets (1935) 265.

20. Hearings before Committee on Banking and Currency on S. 3255, 75th Cong," 3d Sess., (1938) 12.

21. Hearings before Committee on Banking and Currency on S.4023, 74th Cong, 2d Sess. (1936) 31, 32.

22. An exception to this statement may be found in the exchange trading of securities on an unlisted basis. See pp. 641-644, infra. See generally, S.E.C. Report an Trading in UNLISTEd Securities UPON Exchanges (1936).

23. Hearings before Committee on Banking and Currency on S.3255, 75th Cong., 3d Sess. (1938) 13.

24. An officer, director, or 10 per cent holder of equity securities in a corporation whose securities are listed on an exchange must account to the corporation, within certain limits, for his trading profits in the stock of that company. 48 STAT. 896 (1934), 15 U. S. C. \$78p (Supp. 1937). There is no such liability in the over-the-counter market. Hcarings before Committee on Banking and Currency on S. 3255, 75th Cong., 3d Sess. (1938) 13.

25. While there are but 6,000 or so securities listed on exchanges, quotation scrvices subscribed to by over-the-counter firms list over 60,000. See S.E.C. REpont oN TIIE Segregation of the Functions of Dealer and Broker (1936) 67. A comparison may be found in the figures for insurance company securities during the summer of 1937 , when there were $\$ 343,000,000$ of insurance company securities on exchanges as against some $\$ 1,209,000,000$ worth being traded over-the-counter. H. R. Rer. No. 2307, 75th Cong., 3d Sess. (1938) 3. See Address of Chester 'T. Lane before the Seattle Bond Club, S.E.C. Release (March 14, 1938) 2. 
objectives of the original Section 15 of the Securities Exchange Act in which Congress granted the Commission power to regulate the over-the-counter markets. ${ }^{26}$ On the contrary, it represents an attempt to fill in and implement the original outline in order to make possible the realization of the original objectives. ${ }^{27}$ In its form the Mraloney Act merely provides a legal background for regulation. Until actual steps are taken to exercise the powers granted, any comment upon this new legislation must of necessity be confined to a discussion of the problems toward which such activity must be directed and to a comparison of solutions now possible under the Maloney Act with previous attempts to regulate the over-the-counter business by the industry itself.

II.

The Maloney Act is intended to deal with those factors which prevent the over-the-counter markets, in their present unorganized condition, from giving the investing public the same uniformly fair treatment which the Commission has by regulation made available upon the national securities exchanges. ${ }^{23}$ The most important problem in the relations of the over-the-counter markets with the public is that involving the price at which a security may be bought or sold. It is here necessary to differentiate between situations where the investor is sold a worthless or fake security and those in which he is charged more or given less for a bona fide security than its actual value or market conditions warrant. Turning to the case of worthless securities, it is enough to say that no self-regulatory body, even with legal powers to coerce and punish, can hope to cope with the confirmed outlaw. ${ }^{29}$ That the problem of protecting the public from the depredations of purveyors of fake securities still exists is beyond question, but it can best be solved by means of criminal prosecution by a governmental agency acting upon information obtained through the cooperation of representative associations of the members of the business. ${ }^{30}$

However, there exist a number of situations involving trading in bona fide securities which also require rectification. Whether a customer has been fairly treated in his transaction over-the-counter may be measured by two consecutive standards. First, is the price which a customer pays, or gets, for a given security a fair approximation of the current market available in

26. H. R. REP. No. 2307, 75th Cong., 3d Sess. (1938) 4.

27. Id. at 5.

28. See Hearings before Committee on Banking and Currency on S. 3255, 75th Cong," 3d Sess. (1938) 15.

29. "Just as long as there is a man willing to risk penitentiary walls, there will be fellows trying that [selling fake securities]. They will never be governed by any association because they don't care about participation in underwritings that are decent." Joseph C. Hostetler, Counsel for Inrestment Bankers Conference, Inc. Hcarings bcfore Committee on Banking and Currency on S. 3255, 75th Cong., 3d Sess. (1938) 59.

30. See Address of David Sapperstein before the Eastern Group of the National Association of Securities Commissioners, New York, S.E.C. Release (AFarch 19, 1937) 6. 
that security? Second, assuming that the price quoted is as good as any that could have been obtained, are there any manipulative factors affecting the entire market which tend to raise or lower the general price level above or below that which would be arrived at in free competitive trading?

With reference to the question of whether the customer gets the price to which the current market entitles him, there are a number of practices in the over-the-counter markets which have received the attention of the Commission as inimical to public interest. Among such practices the following may be numbered: the tendency of some firms to extract exorbitant profits from their customers; high-pressure merchandising methods; the publication or circulation of bid and asked prices or reports of transactions known to be fictitious; the making of offers to buy or sell at a stated price with no bona fide intent to effect transactions; the failure to make full and unequivocal disclosure to a customer as to the capacity in which a broker-dealer is acting; the subsidizing of competitors' employees; and the making of concealed profits by collusion with other brokers and dealers. ${ }^{31}$

All but one of these practices, that of subsidizing competitors' employees, are made possible and profitable to the unethical broker-dealer by the lack of adequate price information generally available to the public. As has already been stated, it is extremely difficult for a customer to discover what the over-the-counter price of a security really is. ${ }^{32} \mathrm{He}$ has no ticker service to guide him, nor, unless he is constantly trading in a large volume of securities, is he likely to be a subscriber to one of the services which list over-the-counter prices. $^{33}$ Even these are of little value, as they give no indication of buying demand or selling pressure by figures of volume of trading. ${ }^{34}$ Being thus left practically at the mercy of the honesty of the broker he chooses to deal with, the customer runs into the further problem of discovering whether this firm is going to act for him, on its own behalf, or for some third party. The segregation of the functions of broker and dealer has been the subject of much discussion in financial and governmental circles. ${ }^{35}$ In its report in 1936 upon the matter, the S.E.C. concluded that at that time too little was known about the possible consequences of complete segregation in the overthe-counter markets to warrant any definite conclusion. ${ }^{36}$ Certain regulations have, however, been promulgated which tend at least to make it possible for the customer to know whether the house he is dealing with should be treated

31. Address of David Sapperstein before the National Security Traders Association, Los Angeles, California, S.E.C. Release (August 4, 1936) 12, 13.

32. See note 16 , supra.

33. The quotation sheets of the National Quotation Bureau, Inc. and Tre SEcunity DEALERS of NORTH AMERICA are so voluminous that only the experienced trader would know where and how to find any given price bid or asked.

34. Twentieth Century Fund, Tae Security Markets (1935) 265.

35. See S.E.C. Report on the Segregation of the Functions of Dealer and Broker (1936) XIII-XVIII.

36. Id. at 113. 
at arms' length or as a fiduciary. ${ }^{37}$ But the difficulty still remains, for even though the customer knows that the firm he is dealing with is acting upon its own account there is still little or nothing for him to do except talie the price quoted. It is too much to expect an ordinary customer to shop around from firm to firm. Only the large investor, whether an individual or an institution, could possibly afford so to do. ${ }^{38}$

From the foregoing discussion it would appear that one of the needs of the over-the-counter markets is a better and more public system of price quotations designed to give the public some check upon the brokers and dealers to whom it sells and from whom it buys. There are, however, several obstacles to such a solution of this problem. In the first place, the very nature of the unorganized markets makes the task of gathering adequate price data with any reasonable speed extremely difficult, if not absolutely impossible. The great variety and quantity of securities traded and the fact that transactions are consummated at no single place would necessitate an immense amount of labor to report and tabulate prices as trading went on..$^{30}$ To handle such

37. Neither a broker or dealer may effect any transaction for or with a customer unless at or before the completion of the transaction he informs the customer in writing whether he is acting as dealer for his own account, or broker for the customer or as broker for some other person. General Rules and Regulations under the Securities Exchange Act of 1934 as amended, to and including September 10, 1938, Rule X-15cl-4(1). If he acts as broker for the customer, he is under a duty to disclose or offer to disclose the name of the other party and the time of the transaction. He is further required to reveal the amount of his commission or service fee and the amount paid by him to any sub-broker in the transaction. Id., Rule X-15cl-4(2). If he is controlled by, or controls, or is under common control with the issuer of a security involved in the transaction, that fact must be stated. Id., Rule X-15cl-5. A broker or dealer who furnishes investment advice for a consideration or has discretionary powers over a customer's account may not effect any transaction in a security for or with his customer unless he discloses any position, interest or option he may have in such security and obtains written or telegraphic consent of the customer. Neither may such a broler or dealer trade with his customer for an account in which he, or any principal for whom he is acting is interested without similar consent of the customer. Id., Rules X-15el-6, $\mathrm{X}-15 \mathrm{cl}-7$. All of the Rules here cited may be found in 135 C. C. H. 1938 Stock Exchange Reg. Serv. If 5309 C, D, E, F.

38. There are over 2,000 over-the-counter firms in New York City. Mlany firms specialize in certain securities and some make considerable effort to provide a broad and continuous market for their specialties. Twentrern Century Fuxp, Tne Secunis: MARKETS (1935) 265. In a smaller community, it is more than likely that a transaction will involve a number of telephone calls to brokers and dealers in other cities. Under such circumstances the individual customer is precluded from seeing more than a few firms at best, nor has he any way of knowing whether any of these is offering the best price which the existing market warrants. Twestere Centuny Furd, Tne Secund: MIARKETS (1935) 267.

39. The magnitude of the undertaking can be judged from the fact that there are currently some 6,766 firms of brokers and dealers registered with the Commission as transacting business in the over-the-counter markets. For purnoses of comparison, there are only 1,375 members of the New York Stock Exchange. Transactions in the overthe-counter markets are consummated by word of mouth, over the telephone, by telegraph 
a job would require a very large and skilled organization, the cost of which might well be practically prohibitive. In the second place, if some such central price bureau were achieved it would tend to destroy one of the most valuable characteristics of over-the-counter trading, its ability to absorb large blocks of securities without disrupting price trends. It is this factor which at present permits institutions and large private investors to buy and sell with relative freedom from the depredations of speculators who, if they could publicize a large liquidation, might easily create a wave of selling quite unwarranted by the actual value of the security. ${ }^{40}$ The true answer secms to lie not so much in the approximation of exchange quotations for over-thecounter markets but rather in the enforcement of a standard of ethics among brokers and dealers sufficiently high to warrant public reliance upon them not to take advantage of their superior price knowledge under the present system. ${ }^{41}$

The second problem in regard to over-the-counter prices involves their artificial control by various methods of security price manipulation. While it is not as easy to affect over-the-counter prices by some of the devices which were used with such devastating success on exchanges prior to rigorous regulation, ${ }^{42}$ there are, nevertheless, certain ways of obtaining the results desired by unscrupulous speculators. Because of the scattered nature of overthe-counter transactions, collusive agreements between brokers and dealers to sell at certain prices can maintain an artificial price level for some time in a particular locality before news of other and different prices of the same security can break up the control thus obtained. ${ }^{43}$

It has been said that short selling as a manipulative device is confined to the exchanges. ${ }^{44}$ While this statement is generally true in regard to a large proportion of over-the-counter traders, it is a fact that a few firms with access to a supply of the security in which they wish to operate can and do indulge in short selling. ${ }^{45}$ It is known that security affiliates of bankers and

and by mail. To keep any useful check on the trend of transactions would require constant contact with the myriad places where business is done. SEN. REF. No, 1455, 75th Cong., 3d Sess. (1938) 2.

40. S.E.C. Report on the Segregation of the Functions of Denler and Broleg? (1936) $66,67$.

41. Address of William O. Douglas before the Bond Club of Hartford, S. E. C. Release (January 7, 1938) 9.

42. See generally, Berle, Stock Market Manipulation (1938) 38 Cox. L. Ruv. 393; Comment (1937) 46 YALE L. J. 624. For a comprehensive classification of manipulative activity upon exchanges, see Twentietr Century Fund, The Securuty Miniriets (1935) 444 et seq.

43. The Commission has said that "manipulative or deceptive practices in the comparatively unorganized markets are difficult to detect and prevent." S.E.C. REront oN Trading in Unlisted Securities on Exchanges (1936) 18. See Kopald-Quinn \& Co. v. United States, now on appeal (C.C.A. 5th, Nov. Term, 1938) (no district court opinion).

45. S.E.C. Report on Trading in Unlisted Securities on Exchinges (1936) 18. 
other large institutional investors have, in some instances, been able to borrow stock for delivery against short sales with no difficulty whatever.18 Regulation of this type of manipulative device is much more difficult in the unorganized markets than on the exchanges. Such rules as have been promulgated to control short selling on exchanges are entirely dependent upon the availability of a quoted market price.47 With this information, it is possible to tell whether a short sale is intended merely to anticipate a general downward trend or actually to encourage falling prices. ${ }^{48}$ In the over-the-counter markets, rules forbidding short selling at any price lower than the last sale could not be enforced. In the first place, it is practically impossible for any one trader to know what the "last sale" in any given security was; and second, even if the "last sale" could be identified, a number of factors such as the size of the block dealt in, or the difficulty of finding the security, might enter into the price in one case whereas they might not apply in another. ${ }^{* 0}$ As a result, short selling in the over-the-counter markets must be regulated, if at all, by strictures entirely different from those suitable to govern exchange trading. ${ }^{50}$

Another manipulative device in the unorganized market has as its essential element the presence of exchange trading in unlisted securities. The device is simple enough. Buying or selling in volume upon an exchange is not at present defined as a manipulative device although definite price changes may result.51 Where there is a large amount of a security available over-thecounter and a relatively small amount of the same security upon an exchange on an unlisted basis, variations in price upon the exchange, achieved by perfectly legal means, can and do tend to set prices in parallel transactions overthe-counter. ${ }^{52}$ This result is inevitable since, in comparison with the vagueness of over-the-counter quotations, the ticker price on an exchange seems a very authoritative measure of value to the average investor. ${ }^{53}$ It is thus

46. Ibid.

47. "No person shall, for his own account or for the account of any other person, by the use of any facility of any national securities exchange effect a short sale of any security at or below the price at which the last sale thereof, regular way, was effected on such exchange." Rule X-10A-1(a), under Securities Exchange Act of 1934. 135 C. C. H. (1938) Stock Exchange Reg. Serv. \2785B.

48. The fact that the ticker gives a complete record of the volume and price of each transaction makes identification of selling orders to induce bearisls tendencies in the market relatively simple.

49. Hearings before Committec on Banking and Currency on S.3255, 75th Cong., 3d Sess. (1938) 57.

50. Regulation of this manipulative device might talie the form of a requirement that the short seller or his broker disclose the nature of his transaction cither to the commission or a registered association and thus make the fact available to the public.

51. See a discussion of this problem in Berle, Stock Market Mranipulation (1938) 38 COL. L. REv. 393, 405.

52. See Comment (1938) 37 Micr. L. Rev. 98, 102.

53. Hearings before Committee on Banking and Currency on S. 1023, 74th Cong, 2d Sess. (1936) 54. 
possible to control the price in a large volume of securities traded over-thecounter by the trading of relatively small volumes upon an exchange. In this manner speculators may achieve the objective of every manipulative device, price control in the maximum amount of transactions in a given security with a minimum outlay of capital. ${ }^{5 *}$ As a result what would amount to a perfectly legal and economically sound transaction were the security dealt in exclusively upon an exchange or over-the-counter ${ }^{55}$ turns out to be a manipulative device when that security is simultaneously available on both types of securitics markets.

An obvious solution would be to forbid such duplication of markets for any one security. As listed securities are not generally traded over-thecounter, ${ }^{56}$ such a solution would point to termination of the privilege of exchange trading of securities on an unlisted basis. ${ }^{57}$ The Commission has considered this possibility but concluded that so drastic a change would have too disrupting an effect upon trading in these securities with a consequent impairment of their value. 58 The Commission has recommended, and Congress has adopted certain amendments to Section 12(f) of the Securities Exchange Act which provide for the continuation of unlisted security trading upon exchanges only upon given conditions. ${ }^{50}$

Under these amendments, three types of unlisted exchange trading are permitted. The first class includes those securities which were admitted to unlisted trading prior to March 1, 1934. ${ }^{\text {60 }}$ It is with respect to these securitics

54. For a more specific analysis of the purposes of manipulation see Twentretr Century Fund, The Securitx Markets (1935) 444, 445.

55. See note 51, supra. It is not altogether settled that mere buying in voltume is not per se manipulation when there is knowledge that prices will be affected. Sce Securities and Exchange Comm. v. Andrews, S8 F. (2d) 441 (C. C. A. 2d, 1937); Comment (1937) 46 Y ALE L. J. 624, 629.

56. In the bond markets large blocks of bonds that are listed on the exchanges are normally dealt in over-the-counter. They seldom get on the exchanges at all. The blocls that are dealt in on the exchanges might be called retail transactions. See statement of George C. Mathews, Hearings before Committec on Banking and Currency on S. 3255, 75th Cong., 3d Sess. (1938) 12. But as high grade bonds have little speculative appeal they do not enter to any degree into the problem of manipulation of over-the-counter prices by exchange price control.

57. Listed securities, even if available simultaneously on exchanges and oversthecounter, would ordinarily be traded in sufficient volume upon exchanges to makc any attempt at manipulation involve acts already prohibited. But the unlisted securitics arc usually upon exchanges in substantially small volumes. Hearings bifore Committe" on Banking and Currency on S. 4023, 74th Cong., 2d Sess. (1936) 91, 92. In Kopald-Quinn \& Co. v. United States, now on appeal (C. C. A. 5th, Nov. Term, 1938) the device was used with listed securities, but these were available in such limited volume as to malie their situation analogous to the usual situation in unlisted securities.

58. See generally, S.E.C. Report on Trading in UnListed Sicunities on ExChaNGes (1936).

59. See notes 60,65 , infra.

60. 48 Stat. 892 (1934), as amended 49 Stat. 1375 (1936), 15 U. S. C. $\$ 78 l(f)(1)$ (Supp. 1937). 
that adequate information may not be available, and Congress therefore determined that there should be no expansion in this category. The retirement or redemption of securities, the reorganization or liquidation of issuers and the transition of these securities to a fully listed status have effectively diminished this group during the past four years as was anticipated.61 The second type of securities allowed unlisted trading privileges upon a given exchange consists of those which are fully listed and registered upon some other exchange. ${ }^{62}$ Permission to admit a security to exchange trading under this provision is granted by the Commission only upon proof that such action will be both advantageous to the exchange and beneficial to the public. ${ }^{63}$ The third class accorded unlisted exchange trading privileges is comprised of those securities whose issuers provide the Commission with periodic statements, and other data containing information substantially equivalent to that required for the registration and listing of a security on a national exchange. ${ }^{\text {es }}$ Here also the standards of distribution, trading activity and pulblic interest must be satisfied before the Commission will permit the unlisted exchange trading privilege to be granted. ${ }^{65}$

The effect of exchange trading in unlisted securities upon the over-thecounter markets still constitutes a problem which confronts both the Commission and the industry. ${ }^{66}$ The discretion allowed the Commission in granting or denying unlisted trading privileges will be exercised to prevent manipulation of over-the-counter prices by this device, ${ }^{07}$ but the Commission will undoubtedly find it an extremely difficult task to determine when exchange trading in an unlisted security might lend itself to this manipulative device and when it will not. ${ }^{68}$ It is possible that only after the privilege has been granted will the evil become apparent. Discovery at that late date will afford small protection to the already victimized over-the-counter investor. The closer supervision of the over-the-counter markets made possible under the Maloney Act may enable the Commission in cooperation with registered associations to adopt rules which will eliminate the possibility of this evil. Whether

61. Speech of David Sapperstein before Maine Investment Dealers Assaciation, S.E.C. Release (October 27, 1937) 7.

62. 48 Stat. $\$ 92$ (1934), as amended 49 Stat. 1375 (1936), 15 U.S.C. $\$ 783(f)(2)$ (Supp. 1937).

63. 48 Stat. 892 (1934), as amended 49 Star. 1375 (1936), 15 C.. S. C. $\$ 78 I(i)$ (Supp. 1937).

64. 48 Stat. 892 (1934), as amended 49 Stat. 1375 (1936), 15 U.S. C. \$7\&(f)(3) (Supp. 1937).

65. See note 63, supra.

66. For a list of the problems left unsolved by the 1936 amendments to sectiun 12(f) of the Securities Exchange Act see Hearings before Commillec on Banling and Currency on S. 4023, 74th Cong., 2d Sess. (1936) 110-124.

67. Hearings before Committee on Banking and Currency on $S$. ;nzs, Tith Cong., 2d Sess. (1936) 25.

68. See Hearings before Commitfec on Banking and Currency on $S$. 1923, 7th Cong., 2d Sess. (1936) 101. 
such rules will merely require the over-the-counter trader to disclose to his customer the fact that unlisted exchange trading is based on a volume too small to be a correct barometer of value, whether some scheme of price quotation for over-the-counter securities will be devised that will supersede the ticker price in authority in the public mind, or whether the association officials with their intimate knowledge of the business will be able to ferret out the combinations of over-the-counter men and exchange traders participating in manipulation, remains to be seen. Certainly, with close cooperation between government and the registered associations of brokers and dealers some better solution can be devised than has heretofore been available.

\section{III.}

Voluntary attempts at self-regulation within the over-the-counter business have usually taken the form of associations of firms having a common desire to improve relations among themselves and with the public. The Investment Bankers Association is the oldest, one of the largest and the most influential of these organizations. ${ }^{69}$ Under the N.R.A. it lent its wealth of experience to the promulgation of a code which controlled the activities of some 3,200 investment bankers, brokers and dealers. ${ }^{70}$ With the demise of the N.R.A., the Commission and the Investment Bankers' Association joined hands to form the Investment Bankers Conference, Inc., and the latter's cooperation has been invaluable in the Commission's development of the program culminating in the Maloney Act. ${ }^{71}$

Among the brokers and dealers there have also been a number of attempts to achieve self-regulation by means of voluntary associations. $\Lambda$ pioneer group in this field is the New York Security Dealers' Association. It was founded for the purpose of safeguarding the public from the unscrupulous man in the business and thus preserving public confidence in the members of the association. $^{72}$ In spite of its laudable motives it has been unalle to obtain a membership of more than 75 of the 500 New York houses eligible under its rules. ${ }^{73}$ But the California Security Dealers Association met with more success. At present it has a membership of 166 out of some 300 eligible state brokers and dealers. ${ }^{74}$ The association encourages members to maintain a

69. The Investment Bankers Association of America was founded in 1912. Its present membership of about 790 is exceeded only by that of the Investment Bankers Conference, Inc., founded in 1936 through the efforts of the I. B. A. and the Commission, Hearings before Committee on Banking and Curretcy $S$. 3255, 75th Cong., 3d Sess. (1938) 64.

70. Hearings before a Subcomnittce of Committe on Interstate and Forcign Commerce on $H . R .9634, S .3255$, 75th Cong., 3d Sess. (1938) 20.

71. H. R. Report No. 2307, 75th Cong., 3d Sess. (1938) 5, 6.

72. Hearings before Committe on Banking and Currency on $S .3255,75$ th Cong,s 3d Sess. (1938) 40, 41.

73. Ibid.

74. Communication from California Commissioner of Corporations, E. M. Dougherty, to the Yale Law Journal, Dec. 17, 1938. 
reasonable degree of financial responsibility ${ }^{75}$ and its constitution states that it is formed to promote high standards of commercial honor and integrity and in every way to gain public confidence for the investment business. ${ }^{\text {io }}$ It has also adopted and attempts to the best of its ability to enforce rules of fair practice which have had a definite effect in improving the standards of the business in California. ${ }^{77}$

Commendable as such efforts at self-regulation may be, ${ }^{78}$ it remains a fact that these associations cannot by themselves achieve the high standards of conduct which the Commission, the public and the progressive members of the over-the-counter business consider essential. ${ }^{i 0}$ Effective action is prevented by a number of factors. In the first place, there are no sanctions for the enforcement of association regulations. Expulsion from membership can mean no more than a loss of a certain amount of good will since any attempt to discriminate economically against non-members might, in the absence of legislative permission, amount to a violation of state or federal anti-trust laws. ${ }^{80}$ Secondly, the association cannot undertake any comprehensive measures to give its members efficient price data since such efforts might well result in violations of existing law. ${ }^{81}$ With these handicaps it is difficult to overcome the natural antipathy of brokers and dealers toward a program entailing expense and regulation. As a consequence, the small proportion of

75. Unpublished memorandum by California Commissioner of Cornorations, E. M. Dougherty, on History of Self Regulation in California for Securily Dealers (sent to the Yale Law Jourata, Dec. 17, 1938) 2.

76. Articles of Incorporation of California Security Dealers Association, Article II, subsection (b).

77. Communication from California Commissioner of Corponations, E. MI. Dougherty, to the Yale LAw Journal, Dec. 17, 1938.

78. There are, in all, some 23 associations now in existence the purpose of which is to improve conditions in the over-the-counter markets. Communication from Securities and Exchange Commission to the Yale Law Journat, Dec. 16, 1938.

79. See Address of William O. Douglas before the Bond Club of Hartiord, S. E. C. Release (January 7,1938 ) $4,5$.

80. Chamber of Commerce of Minneapolis v. Federal Trade Comm., 13 F. (2d) 673, (C. C. A. Sth, 1926) (rules requiring members of grain exchange to deal with non-members on discriminatory basis held unfair competition and tending to monopoly).

81. It is now clearly established that an exchange may send quotations to such frersons as it sees fit and no others, such quotations being the property of the exchange. Moore v. New York Cotton Exchange, 270 U. S. 593 (1926). But in that ease the quotations were from transactions on the exchange floor. Id., at 605. In the over-the-counter markets quotations could be gathered only from transactions at the various bro!ters' offices. The Commissioner of Corporations states that the Californis Security Dealers Association has been advised by counsel that going too far in the dircetion of giving quotations to association members might incur serious liability. Communication to the YALE LAW JourNal, Dec. 17, 1936. At any rate it remains a fact that associations have been hesitant to undertake any but the most general price quotation scrvices. Since early in 1938, the Investment Bankers Conference, Inc, has collected and disseminated average daily quotations. This service was previously done by the New York Security Dealers Ass'n. 
over-the-counter firms now belonging to associations makes those organizations a relatively ineffective control over the industry. ${ }^{82}$

The Maloney Act successfully puts teeth into associative action. ${ }^{83}$ Now the over-the-counter men have two choices, either to join a registered association and get some voice as to what rules shall govern them, or stay out and be regulated by the Commission. Non-members must bear the burden of being denied brokers' discounts by association firms. ${ }^{84}$ With these factors to give incentive to association membership plus the power of such an association not only to suggest rules but also to enforce them with real economic sanctions, self-regulation becomes a practical reality. ${ }^{85}$ The Maloney $\Lambda$ ct supplies exactly what voluntary self-regulatory attempts have heretofore lacked, power within the business itself to enforce rules and regulations requiring conduct higher in standard than even that which the government could effectively require by law. ${ }^{86}$

IV.

Regulation under the Maloney Act is to be achieved through the combined efforts of associations within the industry and of the Commission. ${ }^{\text {(7 }}$ The status of "registered association" is to be granted any group of over-thecounter firms which meets certain specified qualifications. ${ }^{88}$ Among these are the requirements that the association be either nation-wide in scope or representative of some economically cohesive region ${ }^{39}$ that membership be open to all brokers and dealers who carry on an honest business, exclusion being subject to such rules as the Commission may approve; ${ }^{90}$ and further, that the general pattern of organization be such as to satisfy the Commission that the association seeking to be registered will be able to discharge its function of carrying out the purposes of the Maloney Act. ${ }^{01}$

Non-membership in a registered association will not preclude a broker or dealer from use of the mails or interstate commerce facilities, ${ }^{22}$ nor does

82. See Hearings before Committee on Banking and Currency, S. 3255. 75th Cong., $3 d$ Sess. (1938) 67.

83. See Speech of Francis A. Bonner before annual convention of Investment Bankers Association, S. E. C. Release (October 28, 1938) 5; Address of Robert E. Healy before New York Security Dealers' Association, S. E. C. Release (March 10, 1938) 8 .

84. 52 Stat. 1075,15 U.S. C. $\$ 780-3$ (c) (1) (Supp. 1938). The prohibitions of the anti-trust laws in regard to discrimination against non-members are specifically removed. 52 StAт. 1075, 15 U.S. C. \$78o-3(n) (Supp. 1938).

85. See note 84 , supra.

86. The practical impossibility of the Commission attempting to police the entire over-the-counter industry was pointed out by Commissioner George C. Mathews to the Senate Committee. Hearings beforc the Committec on Banking and Currency on S. 3255, 75th Cong., 3d Sess. (1938) 8.

87. H. R. Rep. No. 2307, 75th Cong., 3d Sess. (1938) 4.

88. 52 Stat. 1075, 15 U. S. C. \$78o-3(a) (b) (Supp. 1938).

89. 52 Stat. 1075,15 U. S. C. $\$ 780-3(b)$ (3) (Supp. 1938).

90. Ibid.

91. 52 Stat. 1075,15 U. S. C. $\$ 780-3$ (b) (7) (Supp. 1938).

92. H. R. Rep. No. 2307, 75th Cong., 3d Sess. (1938) 6. 
membership in a registered association obviate the requirement that he individually must register with the Commission. ${ }^{93}$ Associations are granted the power to enforce their rules and regulations by expulsion of violators, and to require members to do business with any broker or dealer who is not a member of any registered association only at the same prices, commissions and fees as are accorded the general public. ${ }^{95}$ This economic sanction ${ }^{85}$ will undoubtedly encourage membership in the registered associations, since it makes exclusion or non-membership analogous to the loss of a seat upon a national exchange. ${ }^{97}$

The Commission's supervisory power orer the registered association includes the authority to review any cases of exclusion or expulsion from membership ${ }^{98}$ and to supplement association rules in regard to four specified classes of subject matter: (1) rules as to the eligibility and discipline of members; (2) the method for adopting or changing rules of the association; (3) the method of choosing officers and directors; and (4) affiliations between registered associations. ${ }^{93}$ The Commission may also remove any officer or director of an association who wilfully abuses his duty or fails to enforce association rules, ${ }^{100}$ and may expel any member of an association who violates, or does business with anyone who to his knowledge, actual or constructive, is violating, any association or Commission rule as to methods and manner of conducting business. ${ }^{101}$

Section 2 of the Maloney Act provides for the Commission's control of the whole over-the-counter industry including members and non-members of registered associations. ${ }^{102}$ Authority is granted the Commission to pass rules and regulations forbidding the use of mails and interstate commerce facilities to effect over-the-counter transactions which are manipulative, deceptive or fraudulent. ${ }^{103}$ Unlike the rest of the Maloney Act, this provision applies to dealers in municipal and Federal obligations. ${ }^{104}$ Another subsection empowers

93. 52 Stat. 1075, 15 U. S. C. $\$ 780-3$ (a) (2) (Supp. 1938).

94. 52 Stat. 1075, 15 U. S. C. $\$ 780-3$ (b) (9) (Supp. 1938).

95. See note 84, supra.

96. Without this enabling provision in the Act such a rule might amount to a violation of the anti-trust laws. See notes 80, 81, stipra.

97. See address of Robert E. Healy before New York Security Dealers' Ascociation, S. E. C. Release (March 10, 1938) 3.

98. 52 Stat. 1075, 15 U. S. C. $\$ 780-3$ (g) (Supp. 1938).

99. 52 Stat. 1075, 15 U. S. C. \$78o-3(k) (Supp. 1938).

100. 52 Stat. 1075, 15 U. S. C. \$ 7So-3(1) (3) (Supp. 1938).

101. 52 Stat. 1075,15 U. S. C. $\$ 780-3(1)$ (2) (Surp. 1938 ).

102. 48 Srat. 895 (1934), as amended 49 Stit. 1377 (1936), 52 Stıт. 1075, 15 U. S. C. $\$ 78 o(c)(1)(2)(3)$ (Supp. 1938).

103. 48 Stax. $\$ 95$ (1934), as amended 49 St.1т. 1377 (1936), 52 Stit. 1075, 15 U. S. C. $\$ 780$ (c) (1) (Supp. 1938).

104. The original Mfaloney Bill expected to include brokers and dealers who handled municipal bonds exclusively along with the rest of the over-the-counter industry. Hcarings before Committee an Banking and Currenty on $S .3255 .75$ th Cong., 3d Sess. (1933) 1-6. But after vigorous objections by many municipal dea'ers and municiralities the 
the Commission to pass rules and regulations intended to prevent fraudulent, manipulative and deceptive devices and fictitious quotations; ${ }^{105}$ and a final grant allows the Commission to forbid the use of mails and interstate commerce by brokers and dealers who contravene "such rules and regulations as the Commission may prescribe as necessary in the public interest or for the protection of investors to provide safeguards with respect to the financial responsibility of brokers and dealers." 106

The remaining sections of the Maloney Act are included merely to align the new legislation with the existing Securities Exchange Act. Section 3 amends subsection (b) of Section 29 of the Securities Exchange Act so that contracts entered into in violation of regulations regarding financial responsibility shall not be void, and that actions to rescind contracts made contrary to other Commission regulations must be brought within a stated period.107 Section 4 of the Maloney Act excludes violations of Commission rules in regard to financial responsibility from the operation of Section 32 of the Securities Exchange Act except where the violation involves false or misleading statements in reports required by the Commission. ${ }^{108}$

\section{$\mathrm{V}$.}

At the present time, conferences between the Commission and the overthe-counter industry have not yet produced any definite plan for organizing the over-the-counter markets into a scheme conforming with the purposes and objectives of the Maloney Act. ${ }^{100}$ There are several factors, however,

operation of the act was limited to securities designated as non-exempt under the Sccurities Act of 1933. See 52 Stat. 1075, 15 U.S. C. $\$ 780-3(\mathrm{~m})$ (Supp. 1938). As to the wisdom or necessity of this exemption see Address of Robert E. Healy before the New York Security Dealers' Association, S. E. C. Release (March 10, 1938) 6. Compare Hearings before Committee on Banking and Currency on S. 3255, 75th Cong, 3d Sess. (1933) 106, 107.

In the Maloney Act as finally passed, only Section 15(c) (1) of the Securities Exchange Act is made applicable to transactions in municipal, state and Federal securities.

105. 48 Stat. 895 (1934), as amended 49 Stat. 1377 (1936), 52 Stat. 1075, 15 U. S. C. $\$ 780$ (c) (2) (Supp. 1938).

106. 48 Stat. $\$ 95$ (1934), as amended 49 Stat. 1377 (1936), 52 Stat. 1075, 15 U. S. C. $\$ 780(c)(3)$ (Supp. 1938).

107. 48 Stat. 903 (1934), as amended 52 Stat. 1076, 15 U. S. C. $\$ 78$ cc.(b) (Supp. 1938).

108. Section 32 of the Securities Exchange Act provides fines and penalties for violattions of rules and regulations set forth under the Securities Exchange Act of 1934. 48 StAT. 904 (1934), as amended 52 SrAx. 1076, 15 U. S. C. § 78ff.

109. A joint committee representing the Investment Bankers Association and the Investment Bankers Conference has recently recommended that the Investment Bankers Conference modify its present set-up so as to comply with the Maloney Act and allow it to register under the name of Securities Dealers Association. This group has 1553 members and is nation-wide in character and would undoubtedly constitute the largest single association to come under the Act. A drafting committee is now at work on the charter 
which will undoubtedly be considered in the formation of a program, whatever its exact nature may be.

There can be no doubt that the Commission will insist upon some form of regional autonomy in the over-the-counter business. Spokesmen for the Commission have repeatedly emplasized its desire to establish financial selfsufficiency within the several geographic and economic regions into which the Commission considers the United States capable of division. ${ }^{110}$ Regional representation in the registered association set-up contemplated in the Maloney Act could be achieved by any one of three possible devices. First, there could be a number of registered associations, each representing an economically cohesive region; second, there could be one nation-wide registered association with a number of affiliated registered associations; and third, there could be one nation-wide association with provisions for regional representation within its own constitution and by-laws. ${ }^{111}$

For a period of years preceding the Maloney Act, over-the-counter men have criticized the Commission for apparently encouraging and favoring the exchanges at the expense of the unorganized markets.112 That the high standards now enforced by the Commission upon the exchanges have raised their prestige before the public is undoubtedly true, and it is equally correct that with this new confidence, exchanges have pressed to widen the scope of their trading in both listed and unlisted departments. ${ }^{113}$ The action of the Commission in turning to the exchanges first was not prompted by any intent to destroy the importance of the over-the-counter markets. 114 It was a matter of expediency. The problems of the exchanges were known, and close organization made an immediate attack in that direction possible. With the over-the-counter markets action had to be delayed until adequate data upon which to proceed could be obtained.115

The Maloney Act grants the over-the-counter industry an opportunity to raise its own standing with the public to the level already attained by the

and by-laws of the proposed association. Communication from Wallace Fulton, Director of Investment Bankers Conference, Inc, to the YaLE L.iw Jocrast, January 10, 1939.

The Securities and Exchange Commission expects to submit the results of this work to the trade for consideration in the near future. Communication from Henry H. Egly to the Yale Law JourNal, January 10, 1939.

110. See Address of William O. Douglas under auspices of San Francisco Stod: Exchange, S. E. C. Release (June 17, 1938) 4-10.

111. See public letter of W. O. Douglas to J. F. Brown of Denver, Colondo, S. E. C. Release (October 26, 1938).

112. Hearings before Conmittee on Banking and Currency on S. f023, 74th Cong., 2d Sess. (1936) 48-75, 82-99.

113. See Speech of Fenry H. Egly before Investment Bankers Association, S. E. C. Release (Dec. 7, 1938) 3.

114. See public letter of William O. Douglas to W. H. Fulton, Director of Investment Bankers Conference, S. E. C. Release (July 19, 1938).

115. See Hearings before Committee on Banking and Currency on S. 3255, 75th Cong., 3d Sess. (1938) 14. 